\title{
PENGEMBANGAN KOLEKSI UPT PERPUSTAKAAN SEKOLAH TINGGI ILMU PARIWISATA YOGYAKARTA (AMPTA)
}

\author{
Septevan Nanda Yudisman', Bama Suprobojati \\ ${ }^{1}$ Mahasiswa Ilmu Perpustakaan dan Informasi UIN Sunan Kalijaga Yogyakarta \\ ${ }^{2}$ Kepala Perputakaan Sekolah Tinggi Ilmu Pariwisata Yogyakarta (AMPTA) \\ septevannanda@gmail.com
}

\begin{abstract}
ABSTRAK
Pengembangan koleksi di perpustakaan hakikatnya adalah proses mengidentifikasi kekuatan dan kelemahan yang dimiliki suatu perpustakaan yang dihubungkan dengan pengguna yang dilayani. bahan pustaka merupakan koleksi yang dapat menjadi sumber informasi bagi pengguna perpustakaan. bahan perpustakaan yang disediakan yaitu berupa buku, majalah, atau bahan cetak lainnya. Sekolah Tinggi Ilmu Pariwisata Yogyakarta (Ampta) secara berkala melakukan pengembangan koleksi untuk memenuhi kebutuhan sivitas akademika. Pengembangan ini dilakukan secara terkoordinasi dengan seluruh jurusan, Dalam proses penerimaan koleksi buku, sering kali ditemui kendala koleksi tidak sesuai dengan daftar pemesanan. Waktu pengiriman yang lama, sehingga informasi yang terkandung dalam koleksi tidak up-to-date lagi. kebijakan sebuah perpustakaan seharusnya dituangkan dalam bentuk yang jelas sehingga fungsi perpustakaan akan berjalan dengan baik dan dapat diukur sehingga proses pengembangan ke depan dapat dilakukan. Perpustakaan STP AMPTA berkewajiban untuk memberikan pelayanan informasi yang berorientasi pada subyek bidang kepariwisataan, dengan beberapa subyek utama yaitu Pariwisata, Perjalanan Pariwisata, Perhotelan, Makanan dan Minuman, Seni, Budaya, Bahasa, serta Psikologi dengan maksud untuk membantu kegiatan akademik dan mempermudah proses belajar mengajar yang berlangsung dalam lingkungan sivitas akademik Sekolah Tinggi Pariwisata AMPTA Yogyakarta.
\end{abstract}

Kata kunci: Pengembangan Koleksi, Bahan Perpustakaan,Perpustakaan sekolah tinggi pariwisata ampta Yogyakarta

\section{ABSTRACT}

The development of collections in the library is essentially a process of identifying the strengths and weaknesses of a library that associated with the users served. Library material is a collection that can be a source of information for library users. Library materials provided in the form of books, magazines, or other printed materials. The Yogyakarta School of Tourism (Ampta) regularly develops collections to meet the needs of the academics. This development is carried out in a coordinated manner with all departments. In the process of receiving a collection of books, it 
often found that the problem of the collection is not following the list of orders. Long delivery time, so that the information contained in the collection is not up to date. A library's policy should be stated in a clear form so that library functions will run well and can be measured so that the future development process can be carried out. The STP AMPTA Library is obliged to provide information services that oriented to the subject of tourism, with several main subjects namely Tourism, Tourism, Hospitality, Food and Beverage, Arts, Culture, Language and Psychology. Aim of assisting academic activities and facilitating the teaching and learning process which takes place in the academic community of the AMPTA Yogyakarta College of Tourism.

Keywords: Collection Development, Library Materials, AMPTA Yogyakarta high school library

\section{PENDAHULUAN}

Sebuah perpustakaan terbangun dari kumpulan berbagai elemen yang menopang sebuah perpustakaan. elemen tersebut terdiri dari gedung, koleksi, dana operasional dan sumber daya manusia. Salah satu elemen tersebut yaitu koleksi menjadi salah satu elemen penting yang menentukan eksistensi perpustakaan di tengah masyarakat. eksistensi sebuah perpustakaan dapat dilihat dari banyaknya pengguna yang mengakses perpustakaan.

Untuk memenuhi kebutuhan pengguna dari sisi koleksi yang memiliki kuantitas dan kualitas tentu di butuhkan sebuah konsep pengembangan koleksi. Dimana pengembangan koleksi tersebut harus melalui mekanisme yaitu mulai dari merumuskan kebijakan pengembangan koleksi, antara lain menetapkan prioritas pengembangan. Pemilihan bahan pustaka merupakan suatu hal yang sangat penting untuk memberikan layanan yang bermutu. Oleh karena itu prosedur dan mekanisme pemilihan harus digambarkan dengan jelas agar setiap orang terutama pustakawan harus berperan aktif dalam pengembangan koleksi.

Pengembangan koleksi di perpustakaan hakikatnya adalah proses mengidentifikasi kekuatan dan kelemahan yang dimiliki suatu perpustakaan yang dihubungkan dengan pengguna yang dilayani. bahan pustaka merupakan koleksi yang dapat menjadi sumber informasi bagi pengguna perpustakaan. bahan perpustakaan yang disediakan yaitu berupa buku, majalah, atau bahan cetak lainnya.

Bahan pustaka tersebut dapat dapat dikembangkan dengan menambah jenis maupun kuantitasnya. Evans dan saponaro, memberikan batasan istilah "collection development" sebagai suatu proses untuk mengetahui peta kekuatan dan kekurangan atau kelemahan koleksi perpustakaan, sehingga dengan demikian akan tercipta sebuah rencana (Planning) untuk memperbaiki peta kelemahan dan mempertahankan kekuatan koleksi. 
Perpustakaan Sekolah Tinggi Ilmu Pariwisata Yogyakarta (AMPTA) telah menjalankan program kegiatan diperpustakaan namun belum memiliki Pengembangan Koleksi secara tertulis. Maka dengan itu penulis mengambil ini kedalam rencana kegiatan praktikum di Sekolah Tinggi Ilmu Pariwisata Yogyakarta (AMPTA).

\section{TINJAUAN LITERATUR}

\section{Kebijakan Pengembangan Koleksi}

\section{a. Defenisi Koleksi Perpustakaan}

Salah satu unsur perpustakaan yang penting adalah koleksi. Perpustakaan perguruan tinggi bertugas mengelola koleksi perpustakaan. koleksi yang dibangun tidak bisa semata-mata berorientasi pada kualitas atau jumlahnya, namun justru berorientasi pada kualitas dan nilai guna atau pemanfaatan koleksi oleh pemustaka. Lasa Hs menyatakan bahwa koleksi perpustakaan adalah semua informasi dalam benuk karya tulis, karya cetak, dan/atau karya rekam dalam berbagai media yang mempunyai nilai pendidikan, yang dihimpun, diolah dan dilayankan.

\section{b. Kebijakan Pengembangan Koleksi}

Tidak ada suatu kesepakatan bersama dalam mengartikan apakah itu kebijakan.
Montvilof memberikan defenisi kebijakan sebagai seperangkat prinsip dan strategi yang akan menjadi pedoman mengenai tindakan yang akan dilakukan untuk mencapai tujuan yang telah ditentukan sebelumnya. Kebijakan ini bisa dikembangkan dalam level organisai atau institusi (micropolicies), atau juga dalam tingkat regional, nasional, dan internasional (macropolicies).

Kebijakan biasanya berfungsi untuk memastikan bahwa keputusan yang diambil masih sesuai dengan filosofi dan tujuan organisasi. Bryson menilai kebijakan dalam sebuah organisasi dapat digunakan untuk:

a. Menangani masalah yang ada didalam organisasi.

b. Sebagai panduan setiap orang dalam pembuatan kepuusan

c. Memastikan konsistensi dalam pencapaian tujuan organisasi

d. Menjadi panduan dalam menangani masalah-masalah actual

e. Menjelaskan nilai-nilai dan tujuan organisasi

f. Membuat komitmen dengan tujuan organisasi

g. Memenuhi hak-hak staf

Dengan demikian dapat dinyatakan bahwa kebijakan adalah suatu ketepatan yang memuat prinsip-prinsip untuk mengarahkan 
cara-cara bertindak yang dibuat secara terencana dan konsisten dalam mencapai tujuan tertentu. Dengan kata lain kebijakan sebuah perpustakaan seharusnya dituangkan dalam bentuk yang jelas sehingga fungsi perpustakaan akan berjalan dengan baik dan dapat diukur sehingga proses pengembangan ke depan dapat dilakukan.

\section{Pengembangan Koleksi}

Perpustakaan merupakan organisasi yang menyebarluaskan sumber informasi bagi kepentingan penggunanya. menurut Soeatminah pengembangan koleksi merupakan salah satu kegiatan perpustakaan dalam rangka menyediakan koleksi dan pelayanan informasi demi kepentingan pengguna yang sesuai dengan kebutuhannya. Dalam pengembangan koleksi juga diperhatikan bagaimana sesungguhnya kebutuhan pengguna perpustakaan, oleh karena itu pengembangan koleksi perlu dikelola secara professional agar koleksi perpustakaan berkembang sesuai dengan kebutuhan penggunanya. Sedangkan dalam perspektif Curley dan Broderick menjelaskan bahwa pengembangan koleksi merupakan sebuah kegiatan untuk memperluaskan koleksi yang ada di perpustakaan dari sisi seleksi dan evaluasi. Pengembangan koleksi di perlukan dalam sebuah perpustakaan agar tersedia sebuah koleksi yang sesuai dengan kebutuhan penggunanya.

Pengembangan koleksi tidak hanya mencakup kegiatan pengadaan bahan pustaka, tetapi menyangkut masalah perumusan kebijakan dalam memilih dan menentukan bahan pustaka mana yang akan diadakan serta metode-metode apa yang akan diterapkan. Secara umum evans menjelaskan bahwa proses pengembangan koleksi terdiri dari 6 (enam) komponen kegiatan yang terdiri dari: 1) analisis masyarakat; 2) kebijakan pengembangan koleksi; 3) Seleksi 4) Pengadaan 5) Penyiangan; dan 6) Evaluasi.

\section{Fungsi Kebijakan Pengembangan Koleksi}

Disber berpendapat ada banyak dan kegunaan dan fungsi dari kebijakan pengembangan koleksi sehingga sulit dimengerti mengapa banyak perpustakaan yang tidak memilikinya. Menurut yulia secara besar fungsi kebijakan koleksi terdiri dari 3 kelompok yaitu fungsi perencanaan; fungsi komunikai internal;fungsi komunikasi eksternal. Sedangkan manfaat kebijakan pengembangan koleksi yaitu: 
1. Menjadi dokumen untuk sosialisasi kepada masyarakat, sebagai standar untuk menginformasikan kepada setiap orang tentang sifat dan ruang lingkup koleksi

2. Menginformasikan kepada setiap orang prioritas koleksi

3. Mendorong pemikiran tentang prioritas secara organisasi untuk koleksi

4. Menghasilkan komitmen pada tingkat tertentu sesuai dengan sasaran organisasi.menentukan standar untuk materi yang bisa masuk ke koleksi dan mana yang tidak masuk, menghadapi masalah sensor dengan menjelaskan bahan apa yang akan dibeli dan menunjukkan bahwa kebijakan tersebut didukung oleh para administrator lembaga yang bersangkutan.

5. Mengurangi pengaruh dari pemilihan tunggal dan bias pernmorangan.

6. Memberikan sarana pelatihan dan orientasi bagi staf baru

7. Membanu menjamin kekonsistensian dari waktu ke waktu walaupun staf pengelola berganti

8. Memberikan pedoman kepada staf dalam menghadapi protes maupun keluhan dari para pengambil keputusan atau pengguna
9. Membantu dalam menyiangi dan mengevaluasi koleksi

10. Membantu dalam rasionalisasi alokasi anggaran

11. Mmbantu dalam perencanaan anggaran jangka panjang

12. Menjadi sebuah alat dalam menilai kinerja secara keseluruhan dari program pengembangan koleksi

13. Memberikan informasi kepada pihakpihak luar perpustakaan tentang tujuan dari pengembangan koleksi

14. Membantu memilih cara terbaik untuk pengadaan

15. Membantu menetapkan metode untuk menilai bahan sebelum dibeli

16. Membantu merencanakan bentukbentuk kerja sama dengan perpustakaan lain.

\section{Proses Pengembangan Koleksi}

Pada dasarnya, tugas utama setiap perpustakaan ialah membangun koleksi yang kuat demi kepentingan pengguna perpustakaan. pengembangan koleksi mencakup semua kegiatan untuk memperluas koleksi yang ada di perpustakaan, tutama aspek seleksi dan evaluasi.

1) Analisis masyarakat

2) Kebijakan seleksi 
3) Seleksi

4) Pengadaan

5) Penyiangan (Weeding)

6) Evaluasi

\section{METODE PENELITIAN}

Dikarenakan fokus penelitian adalah konsistensi perpustakaan sebagai penyedia koleksi bertema pariwisata, maka dalam penelitian ini, penulis menggunakan rumusan masalah deskriptif kualitatif, dengan harapan dapat menemukan dan memahami fenomena yang akan diteliti pada proses pengembangan koleksi. Penelitian ini menggunakan data primer dan data sekunder. Data primer didapat melalui tiga cara yaitu observasi, wawancara, dan diskusi terfokus (focus group discussion).

Hasil dari observasi lapangan, dipertajam melalui wawancara mendalam terhadap beberapa informan yang dipandang mengetahui permasalahan yang diteliti. Instrumen dari metode ini adalah peneliti sendiri, sehingga peneliti harus memiliki bekal teori dan wawasan yang luas, mampu bertanya, menganalisis dan mengkonstruksikan objek yang diteliti menjadi lebih jelas dan memiliki makna. Peneliti berfungsi menetapkan fokus penelitian, memilih informan sebagai sumber data, melakukan pengumpulan data, menilai kualitas data, analisis data, menafsirkan data dan membuat kesimpulan atas temuannya.

Dalam rangka mewujudkan strategi pengembangan koleksi secara konsisten di Perpustakaan STP AMPTA Yogyakarta diperlukan upaya strategis yang terprogram dan terstruktur. Untuk itulah kemudian diperlukan adanya rencana strategi pengembangan koleksi sebagai pedoman dan arahan dalam konsistensi pengadaan koleksi berbasis pariwisata dengan menggunakan analisis SWOT (Strength, weaknesses, opportunities, threats), dimana analisis SWOT ini dijadikan sebagai suatu model dalam menganalisis suatu organisasi dengan tujuan utama untuk mengetahui keadaan organisasi tersebut secara lebih komprehensif.

\section{PEMBAHASAN}

\section{a. Sejarah dan Latar Belakang}

Unit Pelaksana Teknis Perpustakaan Sekolah Tinggi Pariwisata AMPTA Yogyakarta didirikan pada tahun 1998 dan diresmikan bersamaan dengan kampus utama STP AMPTA Yogyakarta oleh Sri Sultan Hamengkubowono ke X. Sebagaimana 
umumnya sebuah Sekolah Tinggi Pariwisata, perpustakaan berkewajiban sebagai pusat informasi, sekaligus sebagai wadah penyimpanan koleksi berupa buku, khususnya buku mengenai Pariwisata dan ruang lingkupnya. Perpustakaan STP AMPTA berkewajiban untuk memberikan pelayanan informasi yang berorientasi pada subyek bidang kepariwisataan, dengan beberapa subyek utama yaitu Pariwisata, Perjalanan Pariwisata, Perhotelan, Makanan dan Minuman, Seni, Budaya, Bahasa, serta Psikologi dengan maksud untuk membantu kegiatan akademik dan mempermudah proses belajar mengajar yang berlangsung dalam lingkungan sivitas akademik Sekolah Tinggi Pariwisata AMPTA Yogyakarta.

Letak Perpustakaan Sekolah Tinggi Pariwisata AMPTA berada pada sebelah barat gedung utama STP AMPTA dan bertempat dilantai dua yang memiliki luas kurang lebih 150 meter persegi dan terdiri dari ruang pustakawan, ruang baca dan ruang koleksi.

\section{b. Proses Pengembangan Koleksi}

\section{Analisis masyarakat}

Pengguna layanan perpustakaan STP AMPTA Yogyakarta adalah seluruh lingkup civitas akademika yang terdiri dari para Dosen, Karyawan, dan Mahasiswa.

\subsection{Kebijakan seleksi}

\subsubsection{Pelaksana seleksi}

Untuk menyesuaikan bahan pustaka dengan kurikulum kebutuhan kuliah maka perlu adanya seleksi bahan pustaka. Pelaksana seleksi utama penentuan bahan pustaka adalah dosen dan pustakawan STP AMPTA Yogyakarta, sedangkan mahasiswa bersifat usulan dan bebas, tidak terikat pada mata kuliah tertentu dan bisa mengusulkan buku non ilmiah.

\subsubsection{Kriteria seleksi}

Dalam menentukan seleksi bahan pustaka, perlu adanya pertimbangan kualitas sebagai kriteria dalam seleksi bahan pustaka, diantaranya sebagai berikut:

\section{- Kualitas isi}

Sebuah penilaian kualitas sebuah karya tulis dalam bentuk buku terletak pada isi buku tersebut. Kualitas isi diantaranya dapat dinilai dari siapa penulis buku tersebut, dan dosen bisa memaparkan rangkuman isi karya tulis tersebut serta kesesuaian dalam mata kuliah yang diampunya.

- Kualitas fisik

"Don't judge a book by its cover" sepertinya tidak berlaku $100 \%$ untuk saat ini, apalagi untuk menarik minat baca faktor- 
faktor lain seperti kualitas jilid buku yang kuat dan tidak mudah rusak seperti lemnya maupun jahitannya, kualitas cover buku yang menarik, kualitas kertas buku yang baik cerah dan tidak gampang kusut ketika sering dibuka, dan ukuran buku yang ideal tentu menjadi pertimbangan perpustakaan untuk membelinya. Penilaian kualitas fisik tentu bukan yang utama, namun akan bersifat sebagai penarik minat baca.

\section{- Tahun terbit}

Perpustakaan selalu mempertimbangkan kemutakhiran sebuah buku, dimana tahun terbit menjadi suatu hal yang penting, dikarenakan umur pemakaian buku tersebut akan menjadi relatif lebih lama, kandungan isi maupun teori up to date yaitu terbarukan dan selaras dengan materi yang diajarkan dan tetap sesuai dengan kebutuhan saat ini.

\section{- Harga}

Faktor harga dalam pengadaan pembelian buku menjadi hal utama. Dalam pelaksanaannya, perpustakaan rata-rata membeli 3 eksemplar buku yaitu 1 untuk buku tandon dan 2 untuk buku sirkulasi. Dan juga apakah buku tersebut sering dipakai atau tidak, apakah peminat buku tersebut menyeluruh atau hanya sebagai koleksi pelengkap, apakah buku tersebut terbitan luar negeri atau lokal, hal-hal tersebut akan menjadi pertimbangan khusus terkait harga yang sesuai dengan tingginya minat dan kebutuhan pemustaka.

\subsubsection{Bahan pustaka prioritas}

Dalam prosedur pengadaan bahan pustaka, perpustakaan menempatkan prioritas dalam pengadaan untuk beberapa bahan pustaka, diantaranya adalah:

- Buku yang terkait dengan dunia pariwisata dan perhotelan.

- Buku karya dosen STP AMPTA Yogyakarta.

\subsection{Pengadaan}

Pengadaan koleksi bahan perpustakaan serial (jurnal, surat kabar, tabloid, majalah)

\subsubsection{Pengadaan koleksi jurnal:}

- Selain jurnal dalam STP AMPTA Yogyakarta, Perpustakaan juga wajib untuk berlangganan jurnal pariwisata dari luar sebagai syarat wajib.

- Melakukan survey terhadap jurnal yang sudah terakreditasi khususnya jurnal pariwisata. 
- Menghubungi redaksi dari jurnal tersebut untuk proses pendaftaran hingga pembayaran.

\subsubsection{Pengadaan koleksi surat kabar:}

- Menghubungi agen penjualan surat kabar.

- Mengisi formulir berlangganan surat kabar.

- Melakukan pembayaran tiap bulan.

- Saat ini surat kabar yang dilanggan perpustakaan STP AMPTA Yogyakarta adalah: Kompas, Tribun, Kedaulatan Rakyat, Republika.

\subsubsection{Pengadaan koleksi tabloid}

- Menghubungi redaksi tabloid.

- Mengisi formulir berlangganan tabloid.

- Melakukan pembayaran tiap bulan.

- Saat ini tabloid yang dilanggan Perpustakaan STP AMPTA Yogyakarta adalah Media Info Wisata.

\subsubsection{Pengadaan koleksi majalah}

- Menghubungi agen penjualan majalah.

- Mengisi formulir berlangganan majalah.

- Melakukan pembayaran tiap bulan.

- Saat ini majalah yang dilanggan Perpustakaan STP AMPTA Yogyakarta adalah Kabare, Venue.

\subsection{Penyiangan}

Perpustakaan memberlakukan penyiangan berkala setiap satu tahun sekali. Penyiangan bertujuan untuk menyeleksi kembali koleksi buku perpustakaan yang sudah out of date sehingga tidak sesuai dengan kurikulum yang terbaru. Pustakawan memilah secara manual buku-buku yang akan disiangi, dan dirangkum dalam list penyiangan yang nantinya dimintakan persetujuan KUPT. Selanjutnya hasil seleksi tersebut dibuatkan pengajuan dana untuk pengadaan buku-buku yang terbarukan.

\section{c. Evaluasi}

Pemenuhan kebutuhan koleksi perpustakaan harus sejalan dengan kebutuhan pengguna perpustakaan, sehingga sedapat mungkin penyetaraan kebutuhan dilandasi dengan silabus yang ada. Pemanfaatan silabus tersebut berfungsi untuk menyesuaikan kebutuhan dan juga untuk mencari alternatif buku lain yang sesuai tema bahan ajar apabila buku yang dicari tidak dapat ditemukan dipenerbit maupun ditoko buku.

\section{a. Kekuatan (Strength)}

Sebagai pusat informasi ilmu bidang pariwisata di STP AMPTA Yogyakarta, perpustakaan memiliki kekuatan (strength) 
yang dapat dijadikan modal untuk pengembangan koleksi. Berdasarkan hasil pengolahan data dilapangan, terdapat beberapa kekuatan diantaranya:

\section{Potensi sumber daya alam}

Koleksi buku pariwisata perpustakaan STP AMPTA Yogyakarta merupakan salah satu koleksi yang lumayan lengkap untuk wilayah Yogyakarta. Hal ini didapat dari jumlah kunjungan mahasiswa non STP AMPTA Yogyakarta yang seringkali berkunjung untuk mendapatkan referensi bidang pariwisata, tidak hanya itu, dari beragamnya pengunjung perpustakaan, berbanding lurus dengan bertambahnya referensi terkait penambahan koleksi baru terkait pariwisata yang perpustakaan sendiri belum memilikinya.

Disamping itu, jumlah mahasiswa baru setiap tahun semakin meningkat. Sehingga pemasukan dana yayasan semakin besar, dan anggaran untuk pengembangan koleksi perpustakaan juga semakin meningkat.

\section{Potensi sumber daya manusia}

Dalam pengadaan koleksi lokal konten ilmiah, dosen-dosen STP AMPTA Yogyakarta sangat berperan penting dalam penerbitan jurnal ilmiah Media Wisata yang saat ini sudah terbit volume 16 , nomor 1 , tahun 2018 yang terbit dua kali dalam setahun, dan beberapa dosen karya ilmiahnya yang sudah terindeks scopus. Dosen-dosen juga kerap melakukan penelitian ilmiah yang karyanya kerap kali masuk dalam koleksi perpustakaan.

Disamping itu, dari total 34 dosen tetap STP AMPTA Yogyakarta, terdapat 15 dosen yang memiliki karya tulis dalam bentuk buku dan dijadikan referensi bahan ajar bagi para mahasiswa.

\section{Jumlah penerbit yang konsisten menyalurkan buku-buku pariwisata.}

Buku mengenai pariwisata merupakan buku yang susah didapatkan, jikalau ada pasti harganya mahal, terlebih untuk buku-buku perhotelan yang harganya mencapai jutaan dan harus inden agak lama, karena dari penerbit lokal harus membeli dari luar negeri. Hal ini menjadi keuntungan dari beberapa penerbit lokal yang menjadi langganan perpustakaan STP AMPTA Yogyakarta untuk dapat menyalurkan dengan konsisten buku-buku pariwisata diantaranya penerbit ANDI, Graha Ilmu, dan Fenrose Book (buku 
internasional). Dari penerbit juga memudahkan perpustakaan dikarenakan penerbit mengelompokkan koleksi pariwisata dan koleksi umum sehingga seleksi menjadi lebih mudah, dan juga penyebaran katalog penerbit kepada para dosen menjadi lebih mudah pula.

\section{b. Kelemahan (Weakness)}

Di samping adanya kekuatan yang dimiliki, Perpustakaan STP AMPTA Yogyakarta memiliki berbagai kelemahan. Berdasarkan hasil dari pengolahan data yang telah dikumpulkan dilapangan, maka dapat digambarkan kelemahan-kelemahannya sebagai berikut.

\section{Buku pariwisata yang tidak terlalu banyak dipasaran}

Langkanya buku-buku mengenai pariwisata menjadikan koleksi perpustakaan menjadi tidak terlalu banyak. Disamping itu buku yang terbit merupakan koleksi atau edisi lama, namun hanya tahun cetakannya yang terbarukan. Disatu sisi dosen meminta agar buku tersebut edisi yang terbaru dikarenakan untuk kebutuhan mengajar yang dituntut untuk selalu up to date.

\section{Partisipasi dosen dalam penambahan referensi bahan} ajar.

Kurangnya perhatian dosen STP AMPTA Yogyakarta dalam memberikan informasi mengenai referensi bahan ajar, dikarenakan kebanyakan dari dosen lebih memilih referensi dari internet, baik jurnal online, maupun grey literature yang bersifat online, sehingga pustakawan lebih pro-aktif mengumpulkan informasi langsung kepada para dosen.

\section{Kurangnya kerjasama antar perpustakaan.}

Kurang kerjasama antar perpustakaan akan berdampak pada pengembangan koleksi, karena kerjasama antar perpustakaan terlebih dengan Institusi ataupun sekolah tinggi yang memiliki ciri kesamaan dibidang pariwisata, tentunya akan memudahkan dalam hal tukar-menukar koleksi, hibah, maupun penambahan referensi buku bidang pariwisata.

\section{c. Peluang (Opportunity)}

Dalam penelitian pengembangan koleksi Perpustakaan STP AMPTA Yogyakarta, disamping mempertimbangkan faktor-faktor internal, juga harus menggunakan faktorfaktor eksternal yang memungkinkan faktor 
eksternal tersebut sebagai sebuah peluang dalam pengembangan koleksi.

\section{Kebijakan Yayasan Pendidikan Karya Sejahtera dalam meningkatkan koleksi buku pariwisata.}

Dalam membuat kebijakan pengembangan koleksi, tentu tidak terlepas dari dana yang besar. Dana yang besar tersebut disokong oleh Yayasan Pendidikan Karya Sejahtera selaku pendiri STP AMPTA Yogyakarta.

\section{Adanya komitmen.}

Komitmen para penentu kebijakan terhadap pengembangan koleksi akan terus dilakukan hingga perpustakaan tidak kekurangan stok koleksi yang sesuai dengan standar yang telah ditentukan.

\section{d. Ancaman (Threat)}

Selain adanya peluang yang terdiri dari faktor eksternal, pengembangan koleksi perpustakaan stp ampta yogyakarta bertema pariwisata harus mampu mengidentifikasi hambatan atau ancamannya. Berdasarkan hasil observasi serta pengolahan data dilapangan menunjukkan adanya hambatan atau ancaman dalam pengembangan koleksi, diantaranya adalah sebagai berikut.

\section{Dana yang besar.}

Tidak seperti Universitas Negeri mapun Institusi Negeri yang sumber dana seluruhnya disokong oleh pemerintah, STP AMPTA Yogyakarta yang bersifat swasta, sumber dana yang didapat mengandalkan dari jumlah masuknya mahasiswa baru tiap tahun. Oleh sebab itu pengembangan koleksi, terlebih untuk koleksi bidang pariwisata dinilai terlalu berat. Hal ini berdampak pada jumlah koleksi yang tidak terlalu banyak, dan mempengaruhi mutu kualitas.

\section{Literatur online yang tidak kredibel.}

Dosen kerap kali menggunakan literatur online yang tidak jelas asal-usul pengarangnya, kredibilitasnya, dan keabsahan topik yang dimuat karena tidak mencantumkan daftar pustakanya daripada menggunakan buku sebagai referensi utama. Hal ini akan menjadikan kualitas karya tulis yang sifatnya tidak dapat dipertanggung jawabkan secara ilmiah. Dilain hal beberapa dosen menggunakan grey literatur online tersebut sebagai bahan ajar. 
Dari kedua faktor internal dan eksternal yang dijabarkan dalam kekuatan, kelemahan, peluang, serta hambatan atau ancaman tersebut, menurut Fredy Rangkuti (1997) perlu sebuah alat untuk menyusun faktorfaktor strategis yang disebut sebagai matrik SWOT yang terdiri dari strategi SO, strategi WO, strategi ST, dan strategi WT yang dipergunakan untuk menganalisis strategi pengembangan koleksi Perpustakaan STP AMPTA Yogyakarta. Matrik ini dapat menggambarkan secara jelas bagaimana peluang dan ancaman eksternal yang dihadapi perpustakaan sehingga dapat disesuaikan dengan kekuatan dan kelemahan yang dimilikinya.

\section{e. Strategi SO}

Srategi SO merupakan strategi yang menggunakan kekuatan untuk memanfaatkan peluang yang ada guna dirumuskan dalam pengembangan koleksi Perpustakaan STP AMPTA Yogyakarta.

\section{Sumber daya manusia}

Memanfaatkan SDM yang ada serta kesiapan organisasi dalam mendukung pengembangan koleksi Perpustakaan STP AMPTA Yogyakarta yang konsisten terhadap koleksi bertema pariwisata.

\section{Kerjasama dengan penerbit}

Kerjasama dengan berbagai penerbit, terlebih dengan tingkat kebutuhan yang tinggi bisa dioptimalkan dengan cara membeli dengan jumlah yang banyak sehingga diskon yang didapat akan mengurangi beban pengeluaran untuk penambahan koleksi, disamping itu kerjasama dibidang penyebaran promosi penerbit terhadap pemustaka juga menimbulkan keterikatan yang saling menguntungkan dari sisi ekonomi.

\section{Peningkatan minat baca}

Minat baca yang tinggi selalu berdampak positif tidak hanya pada pemustaka, namun juga bagi perpustakaan, terlebih pustakawan yang pro-aktif kepada pemustaka akan memudahkan mendapat referensi yang diambil dari sisi kebutuhan pemustaka.

\section{f. Strategi WO}

Strategi WO dalam pengembangan koleksi Perpustakaan STP AMPTA Yogyakarta merupakan strategi meminimalkan kelemahan untuk memanfaatkan peluang. Strategi WO dijabarkan sebagai berikut. 


\section{Pembelian yang bertahap}

Tidak dipungkiri disamping buku mengenai pariwisata itu langka, namun juga dari sisi harga yang dikategorikan mahal terlebih untuk terbitan internasional, oleh sebab itu perpustakaan secara bertahap namun bersifat berkelanjutan melakukan pembelian buku-buku pariwisata bertaraf internasional.

\section{Promosi katalog penerbit}

Pustakawan berperan dalam melakukan promosi dan merekomendasikan katalog penerbit kepada dosen tetap maupun tidak tetap. Hal ini ditempuh agar kebutuhan pemustaka terhadap buku bahan ajar terpenuhi.

\section{Kerjasama antar perpustakaan}

Peningkatan kerjasama, koordinasi dan penyesuaian MOU antar perpustakaan dengan fokus utama dibidang pengembangan koleksi berbasis pariwisata. Memanfaatkan pertukaran koleksi sehingga koleksi perpustakaan menjadi lebih lengkap.

\section{g. Strategi ST}

Strategi ST merupakan strategi yang menggunakan kekuatan untuk mengatasi berbagai hambatan yang ada. Strategi dalam pengembangan koleksi Perpustakaan STP AMPTA Yogyakarta dapat dirumuskan dengan memanfaatkan berbagai kekuatan untuk menjawab berbagai hambatan atau ancaman. Adapun strategi yang dimaksud adalah sebagai berikut:

\section{Penyuluhan mengenai etika research}

Penelitian yang dihasilkan dengan data yang salah atau dipalsukan, selain tidak mempunyai makna terhadap hakikat penemuannya, juga mempunyai dampak buruk terhadap perkembangan ilmu pengetahuan. Apalagi kalau hasil penelitian dengan data palsu tersebut kemudian dirujuk oleh peneliti lain dan digunakan sebagai acuan, niscaya rangkaian kepalsuan akan menjadi semakin panjang dan berdampak semakin buruk. Oleh karena itu, para ilmuwan dan peneliti harus memegang teguh etika penelitian yang umumnya berlaku secara universal. Pada berbagai himpunan profesi atau lembaga-lembaga riset, etika penelitian biasanya diformalkan dalam bentuk kode etik (codes of conduct) yang mempunyai konsekuensi langsung apabila dilanggar oleh anggotanya. 


\section{Pelatihan sitasi menggunakan references manager}

Penggunaan referensi manajer seperti zotero, mendeley, dan lainnya dalam hal sitasi (citation), merupakan salah satu elemen penting dalam suatu penulisan karya ilmiah. Biasanya penulis pemula seperti, pelajar, mahasiswa, seringkali terjebak dalam plagiasi, yang disengaja maupun yang tidak disengaja dalam membuat sebuah kutipan. Dengan adanya sebuah perangkat lunak yang berfungsi sebagai citation dan reference manager adalah suatu kebutuhan, yang dapat digunakan mengindentifikasi atau melacak kualitas dan keaslian setiap refensi yang digunakan oleh seorang penulis, sehingga dapat meminimalisir penggunaan referensi yang bersifat literatur online yang tidak jelas kredibilitasnya.

\section{h. Strategi WT}

\section{Meningkatkan anggaran}

Sebagai upaya dalam pengembangan koleksi, Yayasan Pendidikan Karya Sejahtera beserta jajaran petinggi STP AMPTA Yogyakarta berkomitmen dalam mengembangkan koleksi perpustakaan yang tentunya perlu adanya peningkatan anggaran.

\section{Studi banding}

Studi banding ke perpustakaan universitas lain dilakukan untuk mengkomparasi dan mengetahui kelemahankelemahan dari sisi manajemen pengembangan koleksi, dan bertujuan untuk mengevaluasinya.

\section{KESIMPULAN}

pengembangan koleksi merupakan salah satu kegiatan perpustakaan dalam rangka menyediakan koleksi dan pelayanan informasi demi kepentingan pengguna yang sesuai dengan kebutuhannya. Dalam pengembangan koleksi juga diperhatikan bagaimana sesungguhnya kebutuhan pengguna perpustakaan, oleh karena itu pengembangan koleksi perlu dikelola secara professional agar koleksi perpustakaan berkembang sesuai dengan kebutuhan

Sekolah Tinggi Ilmu Pariwisata Yogyakarta (Ampta) secara berkala melakukan pengembangan koleksi untuk memenuhi kebutuhan sivitas akademika. Pengembangan ini dilakukan secara terkoordinasi dengan seluruh jurusan, Dalam proses penerimaan koleksi buku, sering kali ditemui kendala koleksi tidak sesuai dengan daftar pemesanan. Waktu pengiriman yang 
lama, sehingga informasi yang terkandung dalam koleksi tidak up-to-date lagi. kebijakan sebuah perpustakaan seharusnya dituangkan dalam bentuk yang jelas sehingga fungsi perpustakaan akan berjalan dengan baik dan dapat diukur sehingga proses pengembangan ke depan dapat dilakukan.

\section{DAFTAR PUSTAKA}

Basuki, Sulistyo. (1991). Pengantar Ilmu Perpustakaan. Jakarta : PT Gramedia Pustaka Utama.

G. Edward Evans dan Margaret Zarnosky Saponaro. (n.d). developing library and information center collection

Yuyu Yulia, Janti Gristinawati Sujana. (2009). Pengembangan
Koleksi.Jakarta: Universitas

Terbuka.

Sri Maryam. (n.d). Upaya mencari solusi pengembangan koleksi di perpustakaan IAIN Syarif Hidayatullah Jakarta. Jurnal Almaktabah, Vol.1, No.2

Direktorat Jendral Departemen Pendidikan dan Kebudayaan. (2005). Buku Pedoman Perpustakaan Perguruan Tinggi. Jakarta: direktorat Jendral Pendidikan Tinggi.

Robert A. Chin. (1991). Disseminating, archiving and retrieving new knowledge in industrial technology: Implication for the discipline and NAIT. journal of industrial technology. Vol.15, number 2. February 1999 to April 19999 